\title{
A Ratiometric Fluorescent Probe for Gold and Mercury Ions
}

\author{
Muhammed Üçüncü, Erman Karakuş, and Mustafa Emrullahoğlu*[a]
}

Abstract: A fluorescent probe that displays a ratiometric fluorescence response towards gold and mercury ions has been devised. Emitting at a relatively longer wavelength, the conjugated form of the fluorescent dye transforms in the presence of the gold or mercury ions into a new dye, the molecular structure of which lacks the conjugation and consequently emits at a distinctly shorter wavelength.

Gold catalysis has recently become a highly popular subject in synthetic chemistry. Its popularity stems from the unique catalytic properties of certain gold ion species, which have been incrementally exploited in the synthesis of complex molecular structures. ${ }^{[1]}$ Though the unparalleled contribution of gold catalysis to synthetic chemistry remains unquestionable, employing metal species such as gold as catalysts in chemical processes raises important health issues concerning the toxicity of gold ion species. ${ }^{[2]}$

In contrast to gold's elemental form, its ionic forms (i.e., $\mathrm{Au}^{+}$ and $\mathrm{Au}^{3+}$ ) are sensitive, extremely reactive, and are able to interact and bind with biomolecules, such as enzymes, proteins, and DNA, thereby disturbing a series of cellular processes and precipitating serious health problems. For instance, it has been documented that the intake of $\mathrm{AuCl}_{3}$ causes damage to vital human organs, including the kidney and liver, as well as the peripheral nervous system. ${ }^{[2]}$

Considering the deleterious effects of gold species on living organisms and their increasing role as catalysts in the chemical industry, it is crucial for researchers to be able to assess the levels of gold species in certain chemical, environmental, and biological samples.

Recently, fluorescence-based techniques for sensing and monitoring target species in solutions as well as in living environments have received a great deal of attention..$^{[3]}$ In this context, several types of fluorescent probes have been devised for analysing gold species. ${ }^{[4]}$ By extension, a variety of fluorophore core units such as rhodamine, ${ }^{[5]}$ boron-dipyrromethene (BODIPY) ${ }^{[6]}$ fluorescein, ${ }^{[7]}$ and naphthalimide ${ }^{[8]}$ have been judiciously modified with specific molecular motifs to recognize gold species through a distinct optical output: colorimetric and/or fluorometric change.

\footnotetext{
[a] M. Üçüncü, E. Karakuş, Prof. Dr. M. Emrullahoğlu

Department of Chemistry, Faculty of Science

izmir Institute of Technology, Urla, 35430, izmir (Turkey)

E-mail: mustafaemrullahoglu@iyte.edu.tr

Supporting information for this article is available on the WWW under http://dx.doi.org/10.1002/chem.201502411.
}

Notably, most existing gold ion sensors are based on specific chemical reactions that exploit the exceptional catalytic behaviour of gold species. In general, the optical signal is recognized as either an increase ("turn-on") or a decrease ("turn-off") in emission intensity without any noticeable change in emission wavelength. Importantly, measurements based on intensity changes are easily influenced by a host of environmental factors, including concentration variations and intensity of excitation.

By contrast, measuring optical signals as intensity ratios at two different wavelengths provides a built-in correction for the environmental effects and may assuage many of the problems associated with intensity-based sensors. Interestingly, the ratiometric recognition of gold ions by a single fluorescent probe structure is currently uncommon. ${ }^{[7 a, 8 b]}$ Two of those examples in recent literature are smart extensions of intensity-based sensors that benefit from the FRET (i.e., fluorescence resonance energy transfer) principle to achieve a ratiometric response. ${ }^{[9]}$

In response, we herein present the design, synthesis, spectral behaviour, and living cell application of a fluorescent probe, BURAK-1, which displays a sensitive, highly selective ratiometric response to gold ions and, surprisingly, $\mathrm{Hg}^{2+}$ ions as well.

In our sensing approach, we drew inspiration from a goldcatalyzed intramolecular cyclization reaction presented years ago by Larock et al. (Scheme 1). ${ }^{[10]}$ It was reported that eny-

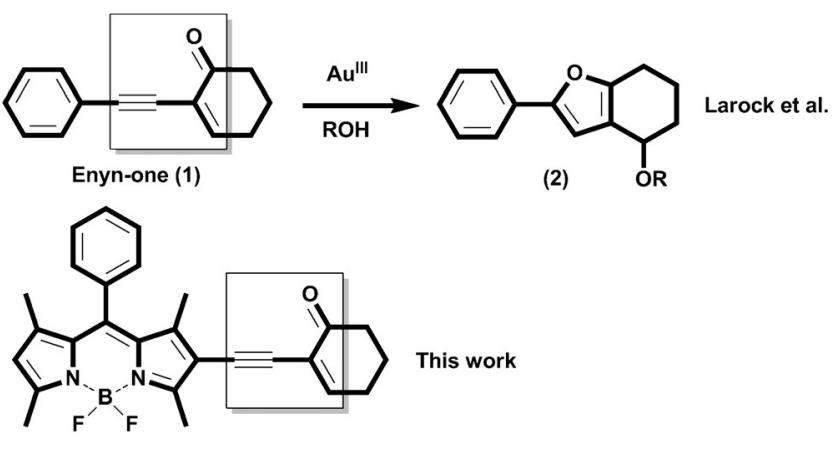

BURAK-1

Scheme 1. Work of both our and the Larock group.

none (1) in the presence of a catalytic amount of $\mathrm{AuCl}_{3}$ transforms rapidly into a new furan (2) derivative. By extension, our attention focused chiefly on exploiting this unique chemical transformation as a signal-transducing event for the recognition of gold ions.

It is well-known that extending the conjugation within a fluorophore-chromophore structure dramatically affects the 
$\mathrm{HOMO} / \mathrm{LUMO}$ levels of molecules and results in a dramatic redshift of its absorption and emission band. ${ }^{[11]}$ With this in mind, we integrated the enynone scaffold to a BODIPY-based fluorophore dye with the expectation of generating a highly conjugated BODIPY derivative emitting at a wavelength distinctly longer than its unmodified form (Scheme 1). We envisioned that only in the presence of gold species would the sensor structure transform itself into another BODIPY derivate lacking the extended conjugation. Gold-ion-triggered structural modification of the fluorescent dye was then anticipated to enable us to recognize the presence of gold species as a ratio of two distinct wavelengths, which is a primary principle of ratiometric sensing.

The title compound BURAK-1 investigated in this study was prepared according to the synthetic route outlined in Scheme 2. Following a Sonogashira coupling protocol, the analysis. The green emissive compound, clearly followed on the TLC plate, was isolated and further characterized by NMR spectroscopy and HRMS as BOD-FUR, the cyclization product of BURAK-1 (Scheme 3). ${ }^{[13]}$ Evidently, the recognition of $\mathrm{Au}^{3+}$ was based on an $\mathrm{Au}^{3+}$-mediated cyclization reaction that resulted in the formation of a highly emissive BODIPY-furane derivative (BOD-FUR).

The systematic titration of BURAK-1 with $\mathrm{Au}^{3+}$ revealed that the ratiometric change of emission intensities at both wavelengths linearly correlated with the increased concentration of $\mathrm{Au}^{3+}$ in the range of $0.005-10 \mu \mathrm{M}$. At the same time, our kinetic study showed that the spectral response toward the addition of $\mathrm{Au}^{3+}$ was rapid ( $<1 \mathrm{~min}$ ) and that emission intensity at $516 \mathrm{~nm}$ plateaued within $40 \mathrm{~min}$ due to the addition of 2 equiv of $\mathrm{Au}^{3+}$, which thereby enhanced intensity at $516 \mathrm{~nm}$ by more than 70 -fold. Moreover, the minimum amount of $\mathrm{Au}^{3+}$ detectable was evaluated to be $8 \mathrm{~nm}^{[13]}$ one of the lowest detection limits reported in fluorescence-based gold ion sensing. ${ }^{[4 a]}$ Meanwhile, a similar spectral trend was observed in the presence of $\mathrm{Au}^{+}$species, revealing that the probe operates efficiently for both oxidation states of gold in a nondiscriminative manner.

Scheme 2. Synthesis of BURAK-1.

acetylene derivative of BODIPY (BODIPY-AC) prepared in three individual steps ${ }^{[12]}$ was coupled with 2-iodocyclohex-2-enone ${ }^{[10]}$ to give the desired probe structure in a moderate yield. The structure of the probe was clearly confirmed by NMR spectroscopic and HRMS analysis. ${ }^{[13]}$

The probe's spectroscopic behaviour toward the added metal species was systematically investigated with the aid of ultraviolet (UV) and fluorescence spectroscopy. As depicted in Figure $1 \mathrm{a}$, the UV/Vis spectrum of free BURAK-1 (phosphate buffer/ethanol 6:4, pH 7.0) displays a maximum absorption band at $526 \mathrm{~nm}$, while its fluorescence spectrum collected upon excitation at $460 \mathrm{~nm}$ exhibits an intense emission band at $562 \mathrm{~nm}$, which belongs to the BODIPY chromophore.

Our investigation resumed with an evaluation of the optical behaviour of BURAK-1 in response to the addition of $\mathrm{Au}^{3+}$ ions (e.g., $\mathrm{AuCl}_{3}$ ). The spectral changes of the probe in the absence and presence of $\mathrm{Au}^{3+}$ ions appear in Figure 1. As shown, the addition of $\mathrm{Au}^{3+}$ ( 2 equiv) to BURAK-1 prompted the appearance of a new emission band at $516 \mathrm{~nm}$, with a concomitant decrease in the emission band at $562 \mathrm{~nm}$. As anticipated, when the probe solution was treated with $\mathrm{AuCl}_{3}$, the orangeemitting probe solution became distinctly green, as was clearly visible to the naked eye (see Figure S28 in the Supporting Information). The dramatic change in colour of the solution was attributed to a change of the BODIPY dye structure. Moreover, green emission was evidence of the existence of a nonconjugated BODIPY derivative.

This suggestion was supported by the outcome of the reaction of BURAK-1 mediated by $\mathrm{Au}^{3+}$, controlled by using TLC
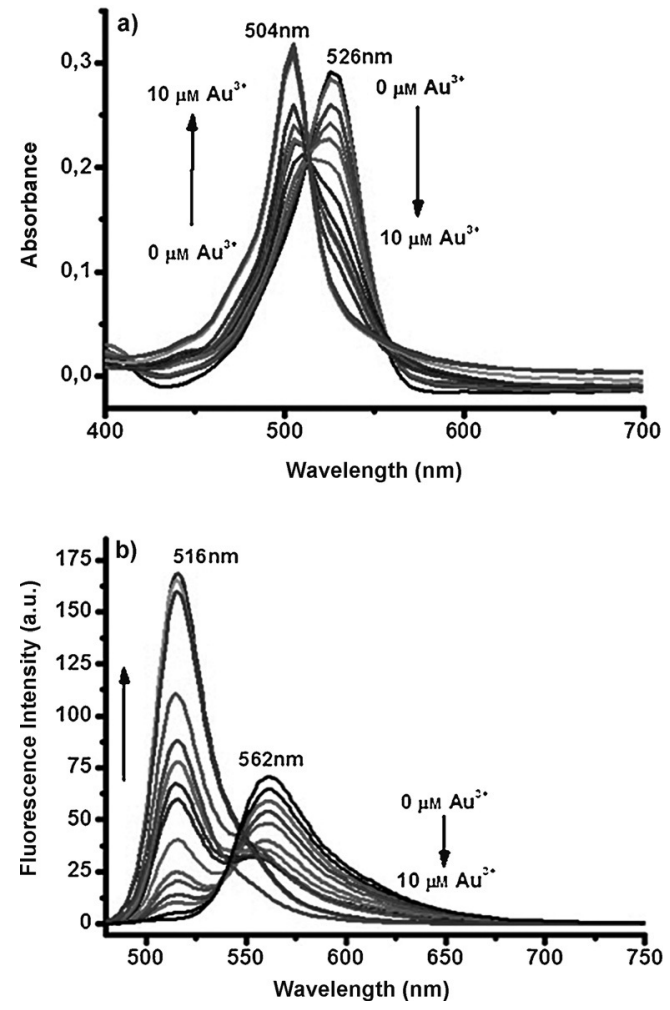

Figure 1. a) Absorbance and b) fluorescence titration spectra of BURAK-1 $(5 \mu \mathrm{M})+\mathrm{Au}^{3+}(0.005$ to $10 \mu \mathrm{M})$ in $0.1 \mathrm{~m}$ phosphate buffer/EtOH $(\mathrm{pH} 7.0, \mathrm{v} / \mathrm{v}$, $6: 4)$. 


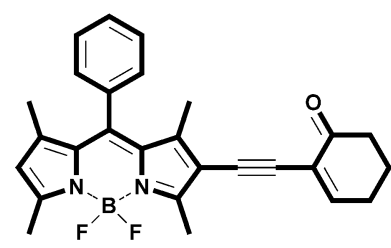

BURAK-1

orange fluorescence

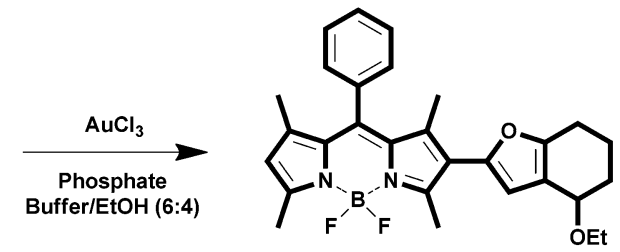

BOD-FUR

green fluorescence

Scheme 3. Gold-mediated cyclization of BURAK-1

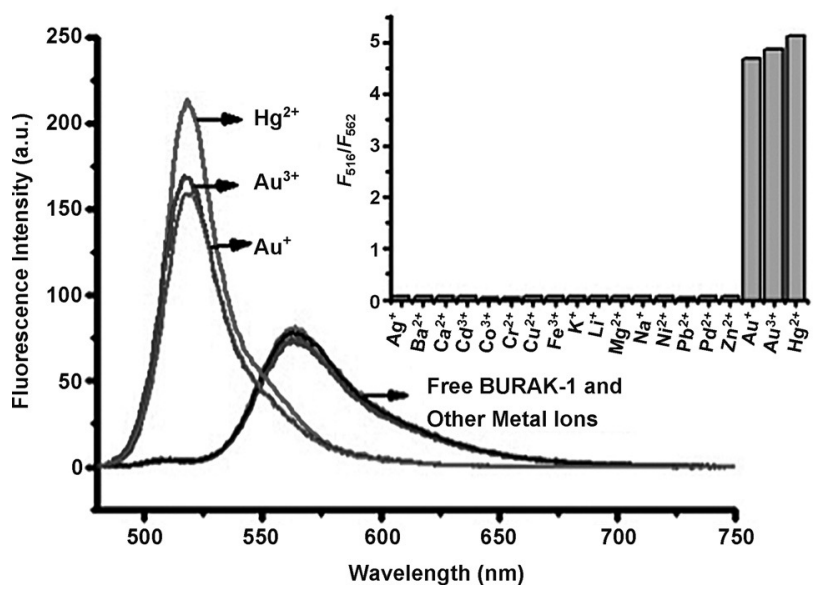

Figure 2. Fluorescence spectra of BURAK-1 $(5 \mu \mathrm{M})$, BURAK-1 $(5 \mu \mathrm{M})+\mathrm{Au}^{3+}$ / $\mathrm{Au}^{+} / \mathrm{Hg}^{2+}$ (25 $\mu \mathrm{M}, 5$ equiv), BURAK-1 $(5 \mu \mathrm{M})+$ other metal ions $(50 \mu \mathrm{M}$, 10 equiv) in $0.1 \mathrm{M}$ potassium phosphate buffer, $\mathrm{pH} 7.0 / \mathrm{EtOH}(\mathrm{v} / \mathrm{v}, 6: 4)$ $\left(\lambda_{\mathrm{ex}}=460 \mathrm{~nm}\right.$, at $\left.25^{\circ} \mathrm{C}\right)$. Inset: Bar graph notation.

The selectivity profile of BURAK-1 was surveyed by screening the spectral response toward metal species, including $\mathrm{Zn}^{2+}$, $\mathrm{Cd}^{2+}, \mathrm{Ba}^{2+}, \mathrm{Cu}^{2+}, \mathrm{Li}^{+}, \mathrm{K}^{+}, \mathrm{Ni}^{2+}, \mathrm{Cr}^{2+}, \mathrm{Mg}^{2+}, \mathrm{Fe}^{3+}, \mathrm{Pb}^{2+}, \mathrm{Hg}^{2+}$, $\mathrm{Co}^{2+}$, and $\mathrm{Ag}^{+}$(Figure 2). Surprisingly, in the presence of $\mathrm{Hg}^{2+}$ ions the probe displayed the exact sensing behaviour as in the detection of gold species. Similar to the gold ion sensing event, with the addition of $\mathrm{Hg}^{2+}$ a new peak band appeared at $516 \mathrm{~nm}$, while the band at $562 \mathrm{~nm}$ decreased with an increased concentration of $\mathrm{Hg}^{2+}$ ions. This unexpected observation was reasonable, for $\mathrm{Hg}^{2+}$ ions similar to $\mathrm{Au}^{3+}$ species are known to have high affinities to alkynes. Notably, the detection limit for $\mathrm{Hg}^{2+}$ was measured to be slightly higher than that for $\mathrm{Au}^{3+}$ ions (60 nм) yet still at nanomolar levels. ${ }^{[13]}$ From the competition experiment, BURAK-1 was ultimately shown to display a dual nature and to efficiently operate for two metal species: $\mathrm{Au}^{+} / \mathrm{Au}^{3+}$ and $\mathrm{Hg}^{2+}$ ions.

Having clarified the nature of detecting both metal species, we next assessed the possible interference of other metal species in the detection of $\mathrm{Au}^{3+}$ and $\mathrm{Hg}^{2+}$. As shown in Figures S7 and S14 (Supporting Information), the response of BURAK-1 toward both species remained unaffected in the presence of other competitive metal species. These results established that BURAK-1 can also properly detect $\mathrm{Au}^{3+}$ and $\mathrm{Hg}^{2+}$ ions in mixtures of other related species.
Further experiments on improving the selectivity of the probe toward one distinct metal species, that is, either $\mathrm{Au}^{3+}$ or $\mathrm{Hg}^{2+}$, revealed that the selectivity toward $\mathrm{Hg}^{2+}$ could be significantly improved by adjusting the nature of the sensing media. Remarkably, in an alternative solvent system, namely, a HEPES/ acetonitrile $(\mathrm{pH} \mathrm{7.0)}$ buffer $(6: 4$ $(\mathrm{v} / \mathrm{v}))$, the probe displayed exceptional selectivity toward $\mathrm{Hg}^{2+}$ ions. Importantly, in HEPES/acetonitrile, particularly at high contents of water (e.g. 6/4; v/v), $\mathrm{Au}^{3+}$ ions were rapidly reduced to gold black (aggregates of elemental gold), which indicates considerable loss of catalytic activity and accounts for the selectivity towards $\mathrm{Hg}^{2+}$. Under these sensing conditions, the detection limit for $\mathrm{Hg}^{2+}$ was evaluated to be $250 \mathrm{~nm} .^{[13]}$ Furthermore, no cross-talk with other metal species in the detection of $\mathrm{Hg}^{2+}$ was detected. Lastly, BURAK-1 shows condition-dependent selectivity toward $\mathrm{Hg}^{2+}$ species and can be used on-demand as a sensitive, selective fluorescent probe for $\mathrm{Hg}^{2+}$ ions.

As consistent with findings reported in the literature, the recognition of $\mathrm{Au}^{3+}$ or $\mathrm{Hg}^{2+}$ is suggested to proceed by a concerted process initiated by the activation of the triple bond by the metal species (Scheme 4). This process follows a conjugate addition of an oxygen nucleophile that promotes intramolecular cyclization and yields a new BODIPY structure appended with a furan motive, which displays the distinct colour and emission of the solution.

Since BURAK-1 constitutes all of the desirable features necessary for tracking species in a living milieu, we assessed its sensing capacity in living cells. To this end, human colon carcinoma cells (A-549) were incubated first with the probe $(10 \mu \mathrm{M})$, to which was added $\mathrm{Au}^{3+}$ or $\mathrm{Hg}^{2+}(10 \mu \mathrm{M})$ to be incubated for another $60 \mathrm{~min}$. The cells were also stained with a nucleus-staining dye (DAPI) for another $10 \mathrm{~min}$. With the aid of
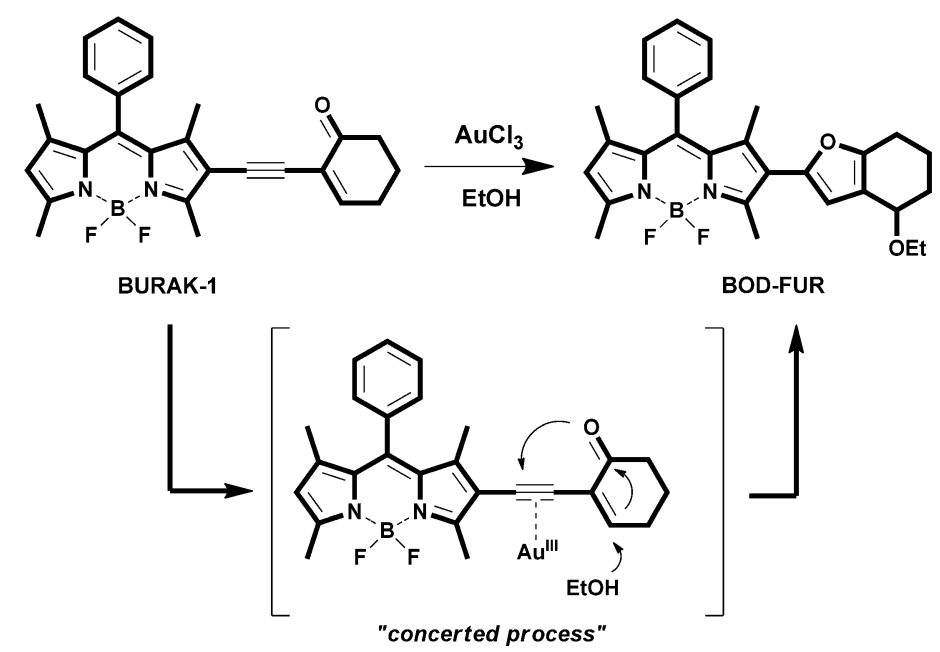

Scheme 4. Proposed reaction mechanism for the detection of gold ions. 
fluorescence microscopy, the fluorescence images of the cells were taken before and after the addition of the metal species. As Figure 3 clearly shows, the cells incubated with BURAK1 emitted a red fluorescence in the absence of the metal species, while following $\mathrm{Hg}^{2+}$ or $\mathrm{Au}^{3+}$ accumulation they emitted

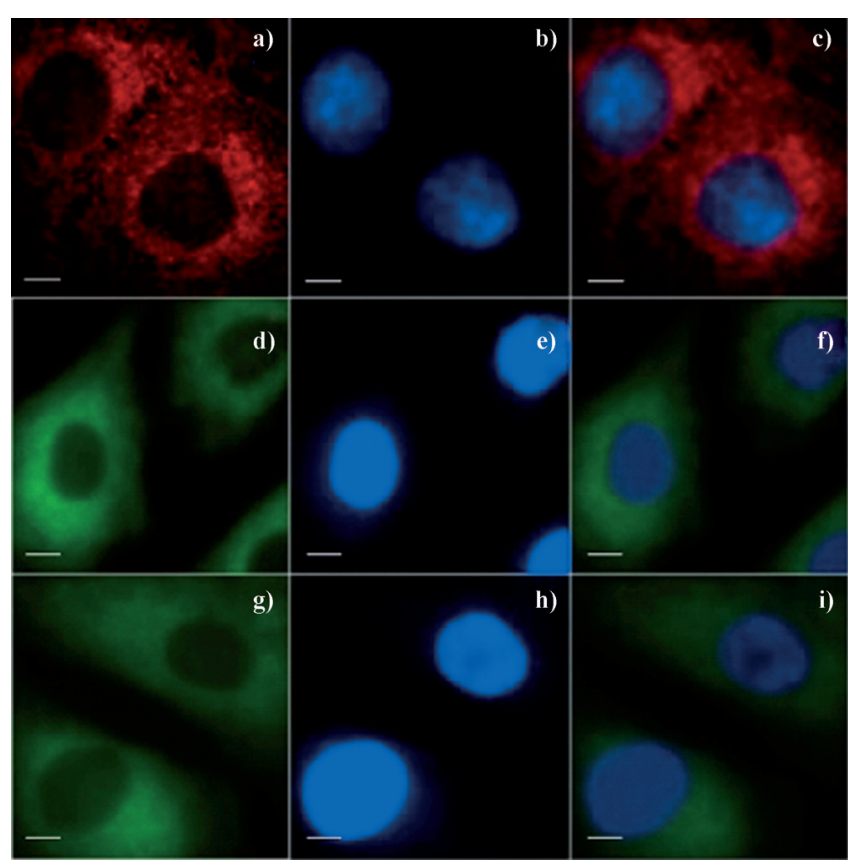

Figure 3. Fluorescence images of Human Lung Adenocarcinoma cells (A549). a) Fluorescence image of A549 cells treated with only BURAK-1 (10 $\mu \mathrm{M})$; $b, e, h)$ Fluorescence image of cells treated with DAPI (control); d,g) fluorescence image of cells treated with BURAK-1 $(10 \mu \mathrm{M})$ and $\mathrm{Au}^{3+}(10 \mu \mathrm{M}), \mathrm{Hg}^{2+}$ $(10 \mu \mathrm{M}) ; c, f, i)$ merged images of frames $a-b, d-e$, and $g-h\left(\lambda_{e x}=460 \mathrm{~nm}\right)$. Scale bar represents $10 \mu \mathrm{m}$.

a characteristic green BODIPY emission, which agrees well with the spectral response obtained in the solution phase. Based on the nucleus counter-stain experiment and from the distinct change in cell fluorescence emission, we conclude that the probe passes through the cell membrane and detects $\mathrm{Au}^{3+}$ and $\mathrm{Hg}^{2+}$ from within the cell, particularly in the cytosol.

In summary, we have devised a unique BODIPY-based ratiometric fluorescent probe that shows a remarkable change in fluorescence emission toward $\mathrm{Au}^{3+}$ and $\mathrm{Hg}^{2+}$ ions with high sensitivity and selectivity over other metal ions. Notably, this probe displays a dual character and can detect both of the metal species with an extremely low detection limit. By adjusting sensing conditions and simply switching the solvent combination, it was also possible to selectively sense $\mathrm{Hg}^{2+}$ ions. Apart from the rapid and specific response to both metal ions in the solution, this probe proved highly successful in imaging gold and $\mathrm{Hg}^{2+}$ species in living cells.

\section{Experimental Section}

\section{General method}

$\left[\mathrm{PdCl}_{2}\left(\mathrm{PPh}_{3}\right)_{2}\right]$ (3.51 mg, 0.05 equiv), Cul $(1.9 \mathrm{mg}, 0.1$ equiv), and BODIPY-AC (69.6 mg, 2.0 equiv) were added to a mixture of 2 iodo-2-cyclohexen-1-one $(22.1 \mathrm{mg}, 0,1 \mathrm{mmol})$ in $\mathrm{THF}$ at $0^{\circ} \mathrm{C}$. Then, diisopropylamine ( $42 \mu \mathrm{L}, 3.0$ equiv) was added and the resulting mixture was stirred at $0^{\circ} \mathrm{C}$ for $1 \mathrm{~h}$. After completion of the reaction, THF was removed under vacuum and the resulting residue extracted three times with $\mathrm{CH}_{2} \mathrm{Cl}_{2}(3 \times 30 \mathrm{~mL})$. The organic layer was dried over $\mathrm{MgSO}_{4}$, filtered, and concentrated. The resultant residue was purified by column chromatography (4:1 (hexane/ethyl acetate)) to afford BURAK-1 as a red solid (31 mg, 70\% yield). ${ }^{1} \mathrm{H}$ NMR $\left(400 \mathrm{MHz}, \mathrm{CDCl}_{3}\right): \delta=7.49-7.48(\mathrm{~m}, 3 \mathrm{H}), 7.27-7.22(\mathrm{~m}, 2 \mathrm{H}), 6.02(\mathrm{~s}$, $1 \mathrm{H}), 2.66(\mathrm{~s}, 3 \mathrm{H}), 2.56(\mathrm{~s}, 3 \mathrm{H}), 2.52-2.45(\mathrm{~m}, 4 \mathrm{H}), 2.04$ (quint. $J=$ $6.4 \mathrm{~Hz}, 2 \mathrm{H}), 1.47(\mathrm{~s}, 3 \mathrm{H}), 1.18 \mathrm{ppm}(\mathrm{s}, 3 \mathrm{H}) ;{ }^{13} \mathrm{C} \mathrm{NMR}(100 \mathrm{MHz}$, $\left.\mathrm{CDCl}_{3}\right): \delta=195.1,157.2,156.5,152.2,144.4,142.9,141.9,134.4$ 132.1, 130.0, 129.0, 127.6, 125.3, 121.8, 114.7, 90.0, 84.7, 37.9, 26.2, $22.2,14.5,14.2,13.2,12.9 \mathrm{ppm}$.

\section{Acknowledgements}

We thank İzmir Institute of Technology (IZTECH) and TUBiTAK for financial support.

Keywords: BODIPY · fluorescent sensors $\cdot$ gold $\cdot$ mercury ratiometric

[1] a) B. Alcaide, P. Almendros, Acc. Chem. Res. 2014, 47, 939-952; b) I. Braun, A. M. Asiri, A. S. K. Hashmi, ACS Catal. 2013, 3, 1902-1907; c) N. Krause, C. Winter, Chem. Rev. 2011, 111, 1994-2009; d) A. Arcadi, Chem. Rev. 2008, 108, 3266-3325; e) A. S. K. Hashmi, M. Rudolph, Chem. Soc. Rev. 2008, 37, 1766-1775; f) Z. Li, C. Brouwer, C. He, Chem. Rev. 2008 $108,3239-3265$.

[2] a) C. M. Goodman, C. D. McCusker, T. Yilmaz, V. M. Rotello, Bioconjugate Chem. 2004, 15, 897-900; b) A. Habib, M. Tabata, J. Inorg. Biochem. 2004, 98, $1696-1702$.

[3] For recent reviews, see: a) X. Li, X. Gao, W. Shi, H. Ma, Chem. Rev. 2014 114, 590-659; b) K. P. Carter, A. M. Young, A. E. Palmer, Chem. Rev. 2014, $114,4564-4601$; c) Z. Guo, S. Park, J. Yoon, I. Shin, Chem. Soc. Rev. 2014, 43, 16-29; d) X. Su, I. Aprahamian, Chem. Soc. Rev. 2014, 43, $1963-$ 1981 ; e) X. Chen, T. Pradhan, F. Wang, J. S. Kim, J. Yoon, Chem. Rev. 2012, 112, 1910-1956.

[4] a) S. Singha, D. Kim, H. Seo, S. W. Cho, K. H. Ahn, Chem. Soc. Rev. 2015, 44, 4367-4399; b) J. F. Zhang, Y. Zhou, J. Yoon, J. S. Kim, Chem. Soc. Rev. 2011, 40, 3416-3429.

[5] a) M. Emrullahoğlu, E. Karakuş, M. Üçüncü, Analyst 2013, 138, 3638 3641 ; b) L. Yuan, W. Lin, Y. Yang, J. Song, Chem. Commun. 2011, 47, 4703-4705; c) O. A. Egorova, H. Seo, A. Chatterjee, K. H. Ahn, Org. Lett 2010, 12, $401-403$; d) M. J. Jou, X. Chen, K. M. K. Swamy, H. N. Kim, H.-J. Kim, S. G. Lee, J. Yoon, Chem. Commun. 2009, 7218-7220; e) Y. K. Yang, S. Lee, J. Tae, Org. Lett. 2009, 11, 5610-5613.

[6] a) C. Cantürk, M. Üçüncü, M. Emrullahoğlu, RSC Adv. 2015, 5, 30522 30525; b) E. Karakuş, M. Üçüncü, M. Emrullahoğlu, Chem. Commun 2014, 50, 1119-1121; c) M. Üçüncü, M. Emrullahoğlu, Chem. Commun. 2014, 50, 5884-5886; d) J.-B. Wang, Q.-Q. Wu, Y.-Z. Min, Y.-Z. Liu, Q.-H. Song, Chem. Commun. 2012, 48, 744-746.

[7] a) H. Seo, M. E. Jun, O. A. Egorova, K. H. Lee, K. T. Kim, K. H. Ahn, Org. Lett. 2012, 14, 5062-5065; b) N. Y. Patil, V. S. Shinde, M. S. Thakare, P. H. Kumar, P. R. Bangal, A. K. Barui, C. R. Patra, Chem. Commun. 2012, 48, 11229-11231; c) S. Kambam, B. Wang, F. Wang, Y. Wang, H. Chen, J. Yin, X. Chen, Sens. Actuators B 2015, 209, 1005-1010.

[8] a) M. Dong, Y.-W. Wang, Y. Peng, Org. Lett. 2010, 12, 5310-5313; b) J. Y. Choi, G.-H. Kim, Z. Guo, H. Y. Lee, K. M. K. Swamy, J. Pai, S. Shin, I. Shin, J. Yoon, Biosens. Bioelectron. 2013, 49, 438-441. 
[9] a) X. Cao, W. Lin, Y. Ding, Chem. Eur. J. 2011, 17, 9066-9069; b) H. Seo M. E. Jun, K. Ranganathan, K.-H. Lee, K.-T. Kim, W. Lim, Y. M. Rhee, K. H. Ahn, Org. Lett. 2014, 16, 1374-1377.

[10] a) T. Yao, X. Zhang, R. C. Larock, J. Am. Chem. Soc. 2004, 126, $11164-$ 11165 ; b) T. Yao, X. Zhang, R. C. Larock, J. Org. Chem. 2005, 70, 76797685.

[11] W. Shi, H. Ma, Chem. Commun. 2012, 48, 8732.
[12] Y. Çakmak, E. U. Akkaya, Org. Lett. 2009, 11, 85-88.

[13] See the Supporting Information for more details.

Received: June 22, 2015

Published online on July 29, 2015 